\title{
Accessibility of Digital Platforms at Universities for Students with Visual Impairment and Blindness
}

\author{
Vojtech Regec, Milan Regec
}

\begin{abstract}
The aim of this paper is to define selected key determinants of accessibility of a digital platform in tertiary education of students with several visual impairments. In the context of tertiary education, it deals with important aspects of the use of semantic HTML tags and elements which to describe an electronic document in an accessible and structured form. We observed the theoretical as well as practical scopes of the use of selected semantical HTML tags for headings and lists from the point of view of blind students. The paper separately elaborates issues related to the implementation of the WAI-ARIA 1.0 landmarks into HTML 5 specification. We conclude through the means of combined qualitative and quantitative research that the accessibility level of digital platforms of universities is unsatisfactory. $63 \%$ of universities did not use correct headings and lists in their digital platforms in 2015, and we did not find a single institution which would be fully compliant with the WAI-ARIA landmarks.
\end{abstract}

Keywords: digital platform, e-Accessibility, visual impairment, blindness, tertiary education, HTML, HTML 5, WAI-ARIA. 


\section{Introduction}

Digitalization of educational and information processes at universities represents a cornerstone of innovative, creative and dynamic education. The proportion of digital tools and digitally shared information is gradually increasing. The implementation of modern technologies to educational processes also increases requirements for technical support in line with digital accessibility requirements. These new tools represent threats as well as opportunities for securing equal access to information and for promoting equal opportunities for visually impaired students, including the implementation of effective anti-discriminatory measures. It is an institution that facilitates the education process (e.g. university), responsible for creating a digital environment compliant with requirements of universal design and the principles of inclusion, thus creating a digital platform that can facilitate academic training and associated services equally for all students, with or without impairment.

In the presented paper we will describe in detail key determinants of accessibility to a digital platform in tertiary education for students with visual impairment where the term digital platform encompasses all digital information, IT services, learning and communication environments a university provides to its students, faculty and related communities. A digital platform includes but is not limited to academic and information systems, digital admissions, student services, learning and course management systems including their content, digital library, library systems and catalogues (OPAC), communication and collaborative environments used in educational processes, other related services and tools for digital data management used in the academic environment.

Chapters are supplemented with data from a combined qualitative-quantitative research conducted throughout year 2015 (for in-depth review of the methodology see Regec 2014; 2015a; 2015b; 2015c). the research sample consisted of 106 universities and higher education institutions (e.g. colleges, for simplicity all are further referred to as universities) in the Czech Republic and Slovakia divided into the following categories:

1. Public universities in the Czech Republic ( $\mathrm{n}^{\text {CzPublic }}=26$ );

2. State universities in the Czech Republic ( $\left.n^{\text {Czstate }}=2\right)$;

3. Private universities in the Czech Republic $\left(\mathrm{n}^{\text {CzPrivate }}=43\right)$;

4. Public universities in the Slovak Republic $\left(n^{\text {SkPublic }}=20\right)$;

5. State universities in the Slovak Republic $\left(n^{\text {skstate }}=3\right)$;

6. Private universities in the Slovak Republic $\left(\mathrm{n}^{\text {SkPrivate }}=12\right)$.

As part of the conducted research we investigated whether the electronic platforms of the sampled universities adheres to the rules defined by the guidelines, methodologies and standards at the national and international levels. Following are the key documents that create the locally enforced legal framework as well as provide checkpoints and useful guides which were used for the evaluation: 
- Methodological instruction to Decree No. 64/2008 Coll.

- Annex No. 1 to Edict No. 55/2014 Coll., on standards for public administration information systems

- Blind Friendly Web 2.3

- Web Accessibility Initiative - Accessible Rich Internet Applications (WAI-ARIA) 1.0

- Web Content Accessibility Guidelines (WCAG) 1.0

- Web Content Accessibility Guidelines (WCAG) 2.0

\section{Accessibility of digital platforms with the use of the WAI-ARIA landmarks and HTML 5 sections}

WAI-ARIA is a technical specification implemented by the World Wide Web Consortium (W3C) in 2014 that introduces tools, guidelines and practices how to increase the accessibility and interoperability of web pages with the focus on dynamic content and user interface components developed with JavaScript, Ajax and related technologies. "Specification provides an ontology of roles, states, and properties that define accessible user interface elements..." (Craig \& Cooper, 2014). The ARIA elements do not interfere with user-agents that do not support them, so adding ARIA to a digital platform does not affect any backward compatibility or limit rich internet applications in any way.

ARIA is based on a role model. Roles are elements with specific pre-defined sets of values that describe their function, semantic level or relation. The value of the role associated with an element must not be changed over time or with user actions. User agents (web browsers, screen readers) can read the roles and use them for effectively operating and navigating rich content and applications using assistive technologies.

Roles are categorized into the following groups:

1. Abstract roles are used to support WAI-ARIA role taxonomy and define general concepts they are not used in the content.

2. Widget roles are used to define and operate a user interface.

3. Document structure roles describe structures that organize content in a page. They are an extension of document structure tags defined in the HTML 5 specification, which are explained in detail below and are not interactive.

4. Landmark roles extend the HTML 5 navigation and describe semantically individual regions of a displayed webpage or application. The correct use of the landmark roles was primary focus of the conducted research.

The landmark roles significantly improve the accessibility of digital documents for users with disabilities by uniquely identifying individual parts of the contents (header, main menu/navigation, main content, footer, etc.). Landmark roles include: 
- $\quad$ role="application" (denotes a region declared as web application, in contrast with web document; user-agents should alter their behaviour respectively, especially when handling keyboard shortcuts);

- $\quad$ role="banner" (for site-oriented rather than page-specific content);

- role="complementary" (supporting sections of the main document at the same hierarchy level that remains meaningful even when separated from the main content);

- $\quad$ role="contentinfo" (usually for copyright and privacy statements, contains information about the parent document);

- $\quad$ role $=$ "form" (navigational landmark denoting a region containing an object that as a whole create a form);

- $\quad$ role="main" (main content of a document);

- $\quad$ role="navigation" (a collection of navigational elements (usually links) for navigating the document or related documents);

- $\quad$ role="search" (related to a form, this is the only case when a form represents a search facility).

It goes without saying that a well organized, hierarchical and semantically marked document can improve comprehension for both visually impaired and intact users. With the help of well-defined reference points using the ARIA landmarks in a digital document, website or application, assistive technology can identify individual parts of the structure, relations between them and their respective functions, and provide its user with an accurate, hierarchically organized document overview. Furthermore, it usually gives the impaired user means of effective navigation between individual parts, better control of an application and minimizes the risk of "getting lost" in complex documents or sites which are frequently present in the academic environment. 
Figure 1

Landmarks from the website of the Support Centre for Students with Special Needs Teiresias at Masaryk University displayed in a tree-form with the free NVDA screen reader from NV Access ${ }^{1,2}$

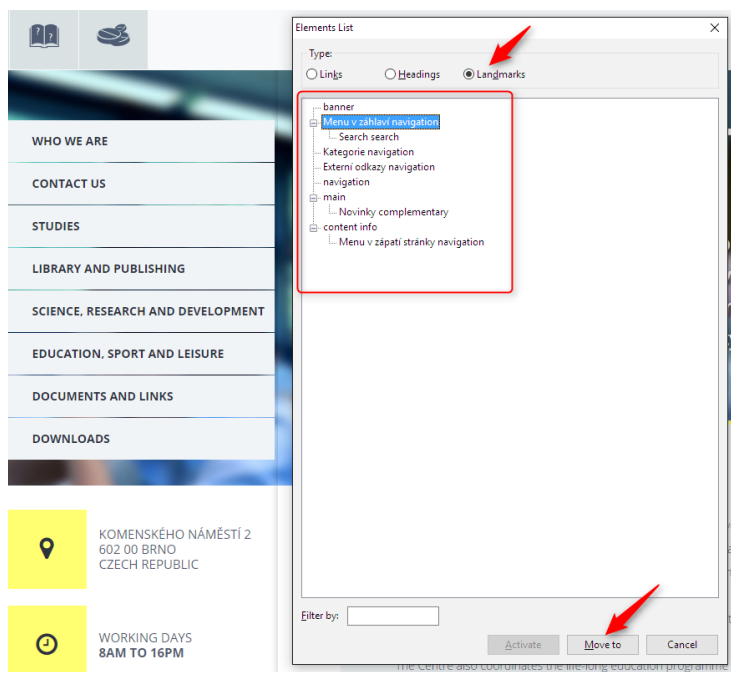

The Teiresias centre also utilizes special labels (aria-label) that further refine the meaning of particular areas for the assistive technology. For example, the string "Menu in the header" defines the type and the location of the navigation panel. Passing this information to the assistive technology and subsequently to its user leads to faster orientation on a yet unfamiliar site.

- $\quad$ < div class="header-link-wrapper right" role="navigation" aria-label="Menu v záhlavi">

With the finalization of HTML 5 in 2014, new semantic elements were implemented and the rest became ARIA-aware because now practically every HTML element can have an ARIA role attribute specified. Tags used in the new HTML 5 semantics to define different parts of a webpage correlate with the WAI-ARIA landmarks (see Tab. 1).

The list of the HTML 5 semantic elements includes: $\langle\text { article }\rangle_{;}\langle\text {aside }\rangle_{;}\langle$details $\rangle$;

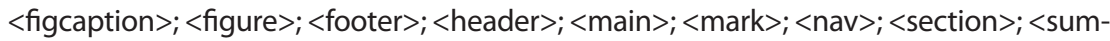
mary $>$; $<$ time $>$.

\footnotetext{
${ }^{1}$ https://www.teiresias.muni.cz/

2 http://www.nvaccess.org/
} 
According to the research by Ibanescu (2011), screen readers JAWS and NVDA were unable to interpret sections defined by the then upcoming HTML 5 standard. However, that is no longer the case. During our own research conducted in 2015, both the screen readers did interpret HTML sections as landmarks correctly (Fig. 2).

\section{Figure 2}

The semantic HTML 5 element <header> recognized as a "banner" landmark by the NVDA screen reader at the home page of Charles University ${ }^{3}$.

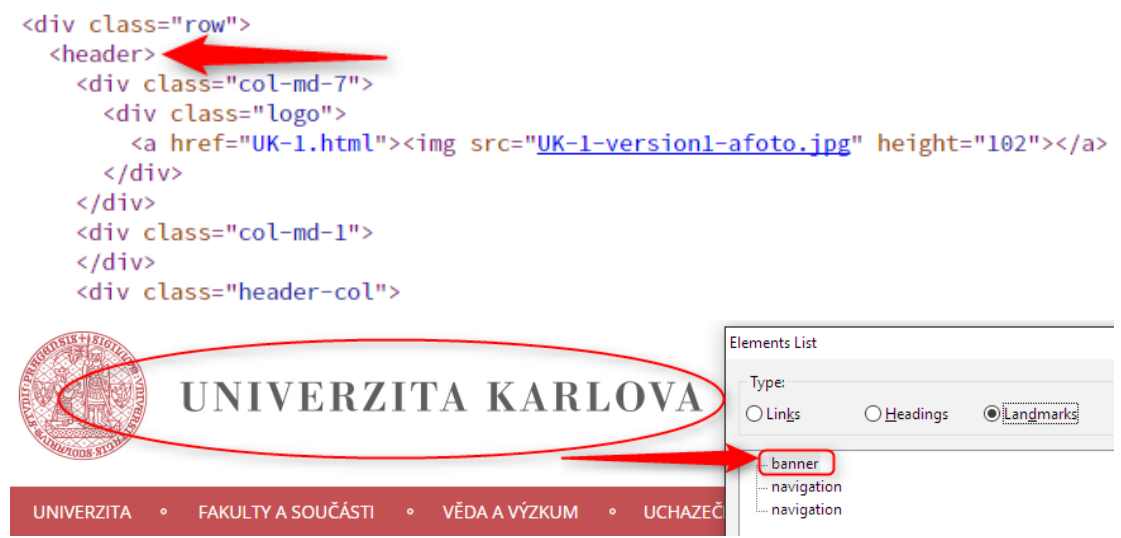

One of the frequently encountered problems in practise is the correct concurrent use of the HTML 5 semantic tags (also referred as sections) with the WAI-ARIA 1.0 landmarks.

Figure 3

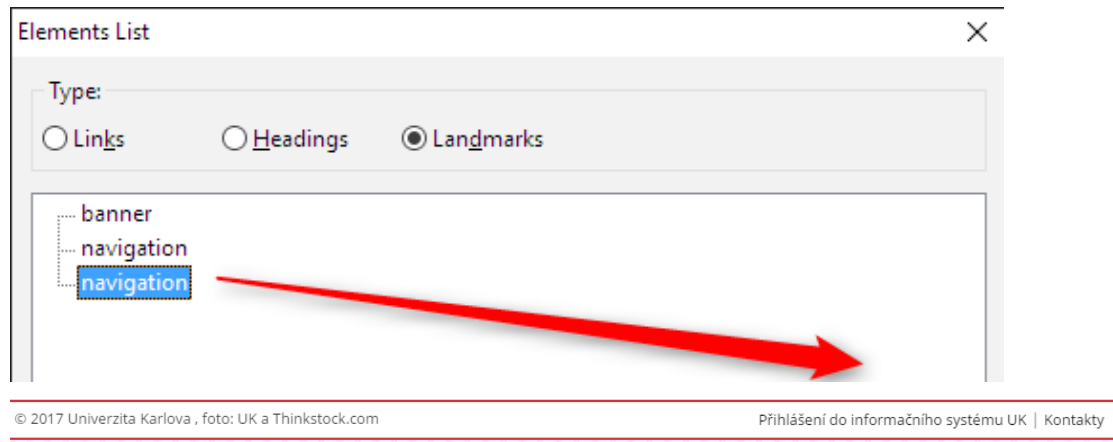

\footnotetext{
${ }^{3}$ http://cuni.cz/
} 
Because of the suboptimal use of a <nav > element, the assistive technology marks the footer area as navigation. In the end it is also confusing for users as there are two different sections identically marked navigations now. The NVDA screen reader parsing the homepage of the Charles University website. ${ }^{4}$

Table 1

Selected semantic elements in the HTML 5 specification and corresponding WAI-ARIA 1.0 landmarks.

\begin{tabular}{|c|c|}
\hline HTML 5 semantic tags & WAI-ARIA landmarks \\
\hline$<$ header $>$ & role="banner" \\
\hline$<$ nav $>$ & role="navigation" \\
\hline$<$ main $>$ & role="main" \\
\hline$<$ footer $>$ & role="contentinfo" \\
\hline$<$ aside $>$ & role="complementary" \\
\hline- & role="search" \\
\hline$<$ form $>$ & role="form" \\
\hline
\end{tabular}

To clear the confusion between the WAI-ARIA landmarks and their HTML 5 related elements, we propose the following best-practices model of their application to basic webpage areas (Fig. 4).

- HTML element <header > should be assigned an ARIA role="banner". This section can include a specific form with role="search", typically used for a site-wide search function.

- HTML element <nav $>$ should be assigned ARIA role="navigation" in the case of global navigation. Property "aria-label" should be further used to distinguish between global navigation of the site and local navigation within the displayed document. For example: $<$ nav role="navigation" aria-label="Site navigation" $>$ for global navigational structure and $<$ nav role="navigation" aria-label="Chapters" $>$ for local navigation within the displayed document. Furthermore, local navigational $<$ nav $>$ can be enclosed with the <aside> tag that, however, does not remove the requirement to use an "aria-label".

- HTML element <main > should be assigned the ARIA role="main".

- HTML element < aside> should be assigned the ARIA role="complementary".

- HTML element $<$ footer $>$ should be assigned the ARIA role="contentinfo".

\footnotetext{
${ }^{4}$ http://cuni.cz/
} 


\section{Figure 4}

Semantical model of a simple webpage divided into areas with the use of the HTML 5 semantic tags and corresponding WAI-ARIA landmarks

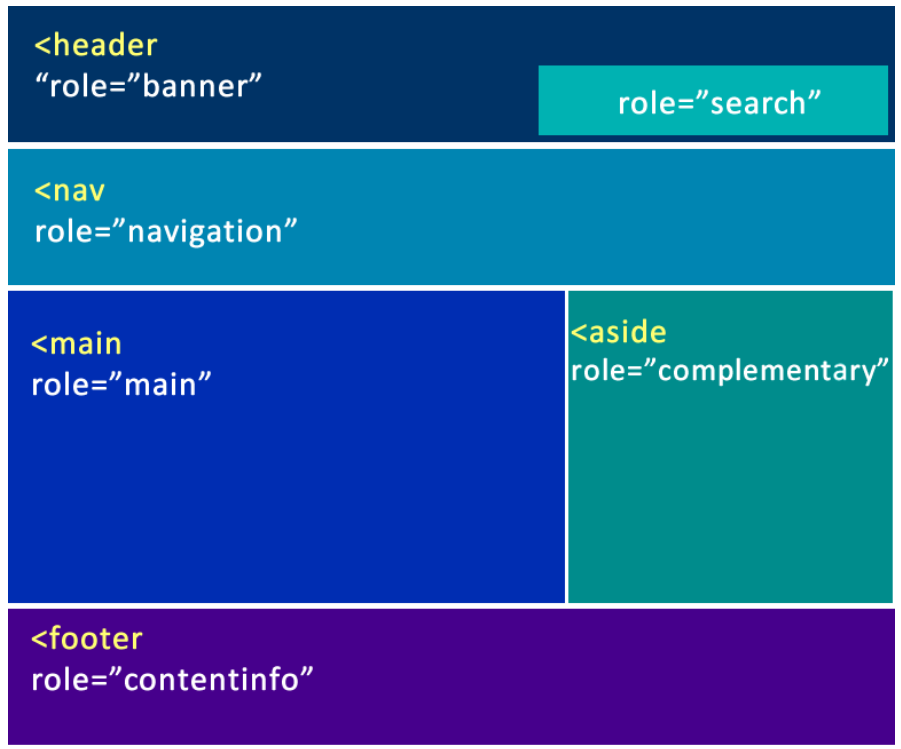

\section{Accessibility of a digital platform and the use of the semantic HTML tags for headings}

Legal framework and standards related to this section:

- WCAG $1.0>$ Checkpoint: 3.5 (Priority 2).

- $\quad$ WCAG 2.0 > Success criteria: 1.3.1 (Level A); 2.4.6 (Level AA); 4.1.1 (Level A).

- $\quad$ Blind Friendly Web 2.3 > Rule: 13.

- Methodological instruction to Decree No. 64/2008 Coll. > Rules: 26; 29.

- Annex No. 1 to Edict No. 55/2014 Coll., on standards for public administration information systems > Point 3.5.

In relation to the above stated checkpoint, we investigated in the conducted research whether the structure of the documents presented within the digital platform of the universities is defined through header elements and whether they are used according their specifications. Besides web and internet application environments (HTML/XHTML 
files), we have also evaluated semantic structures of other documents publicly available for download from the universities' websites as well as selected publicly accessible study materials. Most of these documents were in the PDF, DOC, DOCX and RTF file formats.

Well defined headings play a key role for correct comprehension of the semantics and structure of a document for users with severe visual impairment (Regec, 2014). Accessibility violations were evaluated and assigned one of three categories during the analysis:

\section{Satisfactory/no violation}

- Used technologies do not reduce accessibility for visually impaired and blind users.

\section{Moderate violation}

- The accessibility is moderately affected. ilt can mean in this context that guidelines are followed but inconsistently, or the semantic structure is not always clear or applied according to its purpose (e.g. some of the heading levels are skipped or incorrectly applied). In general, users are able to accomplish the task despite some difficulties.

\section{Severe (significant) violation}

- Information is inaccessible or incomprehensible. It means in this context that the semantic structure of a document is incomprehensible or not defined at all or defined in a way that cannot be relayed to visually impaired users through their assistive technology.

$63 \%$ of universities in the Czech and Slovak Republics did not use correctly applied headings in their digital documents to create a semantic structure in the year 2015. However, the violation was severe only in $10 \%$ of the universities. Differences between the Czech Republic and Slovakia are insignificant, with the exception of the Czech Republic having slightly higher (3.7\%) proportion of the schools with correctly defined semantical structures.

Figure 5. Evaluation of the accessibility of the digital platforms of the universities in the Czech Republic and Slovakia. Proportions in \% of the universities according to their accessibility level in the field of semantically structured documents (application of headings) in $2015(n=106)$.

Key: $\mathrm{V}=$ severe violation; $\mathrm{MP}=$ moderate violation; $\mathrm{V}=$ satisfactory $/$ no violation

Overall, 36.8\% from all 106 evaluated universities used well defined headings in their digital platforms (Tab. 2). Nearly a half of the Slovak public universities and Czech private universities had titles defined in an accessible form. In contrast, two out of three state universities in Slovakia had their digital information in a form inaccessible for visually impaired students. 
Table 2

Findings in the area of a proper use of headings and semantically structured documents on digital platforms at universities in the Czech Republic and Slovakia in year $2015(n=106)$

\begin{tabular}{|c|r|r|r|r|r|r|r|r|r|r|r|r|}
\hline & \multicolumn{2}{|c|}{ CZ Public } & \multicolumn{2}{c|}{ SK Public } & \multicolumn{2}{c|}{ CZ State } & \multicolumn{2}{c|}{ SK State } & \multicolumn{2}{c|}{ CZ Private } & \multicolumn{2}{|c|}{ SK Private } \\
\hline & \multicolumn{1}{c|}{$n$} & \multicolumn{1}{c|}{$\%$} & \multicolumn{1}{c|}{$n$} & \multicolumn{1}{c|}{$\%$} & \multicolumn{1}{c|}{$n$} & \multicolumn{1}{c|}{$\%$} & \multicolumn{1}{c|}{$n$} & \multicolumn{1}{c|}{$\%$} & \multicolumn{1}{c|}{$n$} & \multicolumn{1}{c|}{$\%$} & \multicolumn{1}{c|}{$n$} & $\%$ \\
\hline V & 8 & 30.8 & 9 & 45.0 & 0 & 0.0 & 0 & 0.0 & 19 & 44.2 & 3 & 25.0 \\
\hline MP & 15 & 57.7 & 10 & 50.0 & 2 & 100.0 & 1 & 33.3 & 20 & 46.5 & 8 & 66.7 \\
\hline VP & 3 & 11.5 & 1 & 5.0 & 0 & 0.0 & 2 & 66.7 & 4 & 9.3 & 1 & 8.3 \\
\hline$\Sigma$ & 26 & 100.0 & 20 & 100.0 & 2 & 100.0 & 3 & 100.0 & 43 & 100.0 & 12 & 100.0 \\
\hline
\end{tabular}

The most prevalent accessibility violation was in the form in an incorrect use of headers $\langle$ h $1>$ to $\langle$ h $6>$ for titles in the source code of the universities' websites. One of the examples of such a case where headers are missing completely can be seen at Fig. 6, which depicts a screenshot from the academic information system of Palacký University Olomouc, currently also used at other universities across the Czech Republic.

\section{Figure 6}

Visually styled heading that is inaccessible as a title for assistive technologies. (Academic information system of Palacký University Olomouc ${ }^{5}$ )

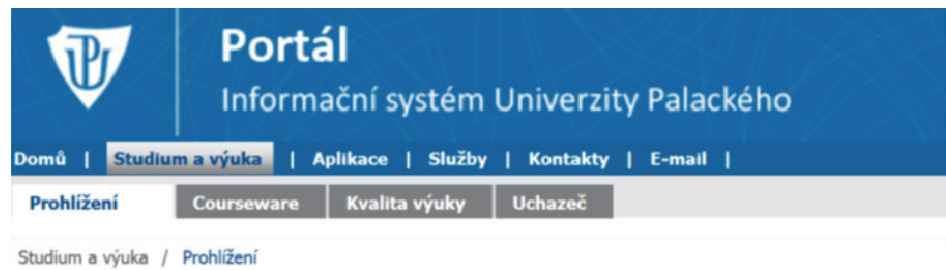

\section{Prohlížení}

\begin{tabular}{|c|c|c|c|c|}
\hline E Programy a obory & | Předmĕ & & & \\
\hline = Předměty & - Hledáni & n & podle zz & daných parametrû \\
\hline $\begin{array}{l}\text { = Pracoviště } \\
\text { = Učitelé }\end{array}$ & $\begin{array}{l}\text { Zkratka } \\
\text { pracovištĕ }\end{array}$ & $\%$ & $\underline{\mathrm{g}}$ & Zkratka "V" $\%$ od "2009" to \\
\hline $\begin{array}{l}\text { - Studenti } \\
\text { - Zkouškové terminy }\end{array}$ & $\begin{array}{l}\text { Vyučováno v } \\
\text { jazyce }\end{array}$ & $\%$ & $\cdot$ & $\begin{array}{l}\text { Zpúsob } \\
\text { zakončeni }\end{array}$ \\
\hline
\end{tabular}

Related line in the source code used for the title Předmèt:

- $\quad<$ div class="prohlizeniEntitaHead_left" $>$ \&nbsp;Předmět $</$ div $>$

\footnotetext{
${ }^{5}$ https://portal.upol.cz/wps/portal/StudyingAndTeaching.
} 
The code above is completely avoiding any semantic tags and its custom class is undetectable with assistive technologies. In this case the cause of violation can be described as not using header elements $\langle\mathrm{h} 1\rangle$.. $<\mathrm{h} 6\rangle$ according to their specification.

Automated analytical tools can also provide helpful feedback to detected accessibility violation described above. Fig. 7. shows a free "WAVE web accessibility evaluation tool" reporting alert of a possible heading not being properly semantically marked.

\section{Figure 7}

Alert of a potential digital barrier caused by a possible heading not semantically marked, reported by the automated WAVE - web accessibility evaluation tool. ${ }^{6}$

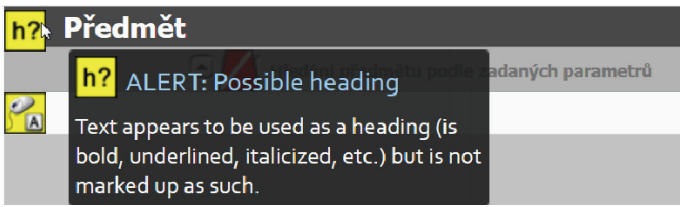

Another example of visually represented titles without a proper semantic markup in the source code can be found at Technical University of Liberec (Fig. 8). These titles are invisible for navigation tools of the assistive technologies. In the source code, we can see that a custom class "header" is solely used instead of semantic heading tag $\langle\mathrm{h} 1\rangle . .<\mathrm{h} 6\rangle$ for the purpose of the eCSS formatting.

\section{Figure 8}

Titles presented visually but without a proper semantic markup at Technical University of Liberec ${ }^{7}$

TECHNICKA UNIVERZITA V LIBERCI
www.tul.ca

\footnotetext{
${ }^{6} \mathrm{http}: / /$ wave.webaim.org/

7 http://www.tul.cz/
} 
$</$ div $>$

<div clase-ll otum columns-10ur controlcolumn-uni-news">

〈div class="header" $>$ Univerzitní novinky</div $\rangle$

$<$ li class="news-item" $>\langle$ div class="title" $>$ Majáles $\mathrm{cl}$ $\langle$ p $\rangle\langle$ img class="news-inage" src="http://tuni.tu: Počasí navléklo návštěvníky letošního majálesu

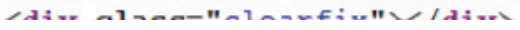

\section{Accessibility of a digital platform and the use of the semantic HTML tags for lists}

Legal framework and standards related to this section:

- WCAG $1.0>$ Checkpoint: 3.6 (Priority 2).

- WCAG 2.0 > Success criteria: 1.3.1 (Level A); 4.1.1 (Level A).

- Blind Friendly Web $2.3>$ Rule: 13.

- Methodological instruction to Decree No. 64/2008 Coll. > Rules: 26; 29.

- Annex No. 1 to Edict No. 55/2014 Coll., on standards for public administration information systems > Point: 3.6.

Along with the properly semantically marked titles, well-formed and hierarchically structured links are essential for enabling students with severe visual impairment or blindness to comprehensively and effectively navigate a website, application or digital document.

During the research period of 2015 , our focus in the field of links was primarily on evaluation of the proper placing and form of site-map and global navigation. Hierarchically structured elements are required in both the cases in order to form a site with navigation accessible and operable by the assistive technologies and their users, especially those using screen readers.

Accessibility violations were evaluated and assigned one of three categories during the analysis:

1. Satisfactory/no violation

- The used technologies do not reduce the accessibility for visually impaired and blind users. lit may mean in this context that regions containing navigation are properly marked using a $<$ nav $>$ tag and/or ARIA landmark, and individual elements are properly hierarchically structured. 


\section{Moderate violation}

- The accessibility is moderately affected. Navigation might be missing a semantic $<$ nav $>$ tag or ARIA role="navigation" landmark, but navigation is still executed through the links organized in a structured way that is accessible.

\section{Severe (significant) violation}

- Information is inaccessible or incomprehensible. It means in this context that a sitemap is missing, and/or global navigation is not organized in a list at all. Blind users are unable to navigate the site without assistance.

Figure 9

80.0

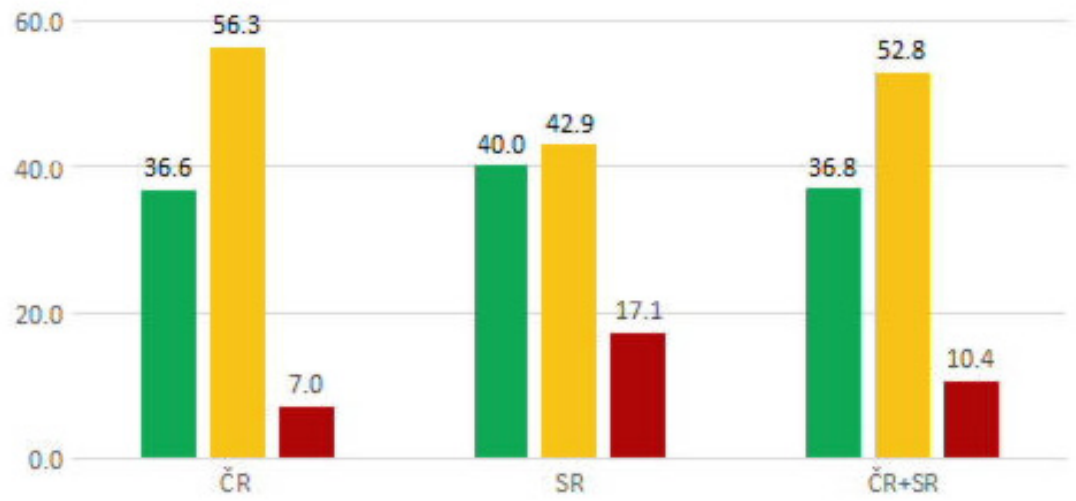

Evaluation of the accessibility of digital platforms of the universities in the Czech Republic and Slovakia. Proportions in \% of universities according to their accessibility level in the field of hierarchically structured lists (applied to global navigation and site-map) in $2015(n=106)$.

Key: $\mathrm{V}=$ severe violation; $\mathrm{MP}=$ moderate violation; $\mathrm{V}=$ satisfactory $/$ no violation

While not using semantically marked titles in a document or site properly may lead to information being incomprehensible, difficult to retrieve and hard to work with, a wrongly designed navigation section often means that users most likely will not be able to reach desired information at all.

Our research marginally showed better results in the group of universities that had met criteria for the lists as compared with the accessibility situation in the field of the 
semantically correct use of headings. Best results were observed at private universities (58.3\% satisfactory levels), and vice versa, the highest proportion of severe violations was recorded at state universities (Tab. 3).

Table 3

Evaluation of the accessibility in the area of structured lists (navigation) at universities in the Czech Republic and Slovakia in year $2016(n=106)$

\begin{tabular}{|c|r|r|r|r|r|r|r|r|r|r|r|r|}
\hline & \multicolumn{2}{|c|}{ CZ Public } & \multicolumn{2}{c|}{ SK Public } & \multicolumn{2}{c|}{ CZ State } & \multicolumn{2}{c|}{ SK State } & \multicolumn{2}{c|}{ CZ Private } & \multicolumn{2}{|c|}{ SK Private } \\
\hline & \multicolumn{1}{c|}{$n$} & \multicolumn{1}{c|}{$\%$} & \multicolumn{1}{c|}{$n$} & \multicolumn{1}{c|}{$\%$} & \multicolumn{1}{c|}{$n$} & \multicolumn{1}{c|}{$\%$} & \multicolumn{1}{c|}{$n$} & \multicolumn{1}{c|}{$\%$} & \multicolumn{1}{c|}{$n$} & \multicolumn{1}{c|}{$\%$} & \multicolumn{1}{c|}{$n$} & $\%$ \\
\hline V & 7 & 26.92 & 6 & 30.0 & 0 & 0.0 & 1 & 33.33 & 19 & 44.19 & 7 & 58.33 \\
\hline MP & 14 & 53.85 & 12 & 60.0 & 2 & 100.0 & 0 & 0.00 & 24 & 55.81 & 3 & 25.00 \\
\hline VP & 5 & 19.23 & 2 & 10.0 & 0 & 0.0 & 2 & 66.67 & 0 & 0.00 & 2 & 16.67 \\
\hline$\Sigma$ & 26 & 100.00 & 20 & 100.0 & 2 & 100.0 & 3 & 100.00 & 43 & 100.0 & 12 & 100.00 \\
\hline
\end{tabular}

Fig. 10 shows the example of not properly structured list elements forming a site map. Elements are structured with indentation using the inline CSS style attribute, however semantically all of them are at the same level, thus providing different experience to intact vs. visually impaired users who cannot perceive the information about hierarchy unless it is properly defined.

Figure 10

Incorrectly formed site map at Janáček Academy of Music and Performing Arts in Brno. Despite the fact that an unordered list is used, it is missing a hierarchical structure ${ }^{8}$.
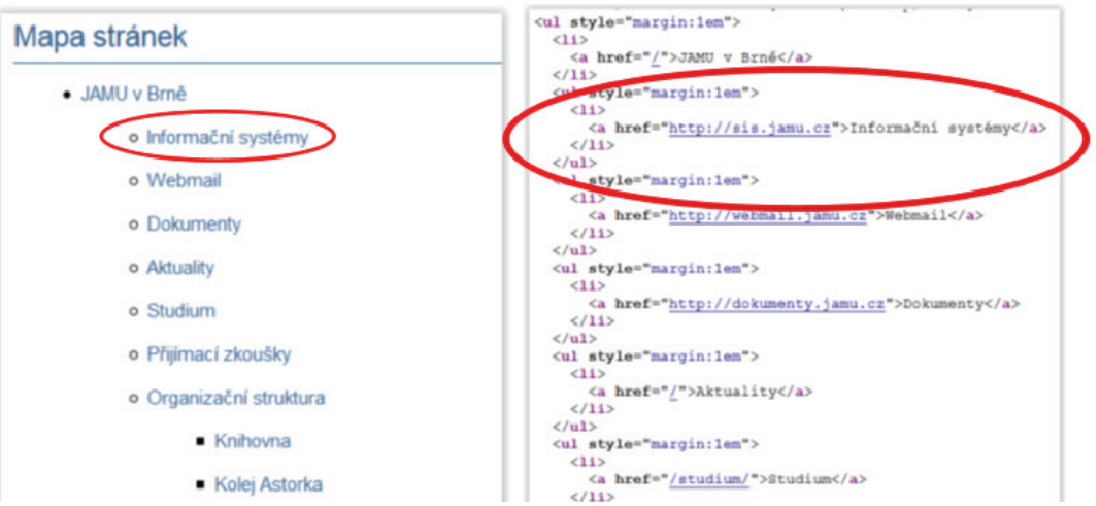

${ }^{8}$ http://www.jamu.cz/sitemap.html. 
Another common mistake is often present when a webpage has more navigational regions, such as global and local navigation, a list of external links. Better description should be used when labelling these so that users do not end up presented with three different top level regions marked simply as "navigation".

\section{Conclusion}

Our research conducted in 2015 in the Czech and Slovak Republics showed that only about one-third of the evaluated universities $(n=106)$ has their digital platforms accessible at a satisfactory level, and about 10 percent has their digital content inaccessible by blind users. Despite being adopted more than two years ago, the ARIA landmarks and HTML5 semantic tags are not used by universities or are often used incorrectly. The present situation is also a violation of good but weakly enforced legislation; nonetheless universities should wake up and boost their accessibility efforts before it will be too late.

Mitigation of this unfavourable state is relatively easy and not costly. The structure of regions of a website can be easily adjusted by making corrections to the templates. Navigation and site maps are regions often generated automatically and repeated everywhere, so one correction can instantly fix the entire site. The HTML5 semantic elements and WAI-ARIA landmarks offer simple, backwards compatible solutions that provide great comfort to visually impaired users while not affecting the experience in any way for anybody else.

Digitalization is a great opportunity to support participation and quality services and content delivery to students with visual impairment, however currently it still presents a significant digital barrier. The situation needs to be monitored and evaluated and properly communicated with the management, together with other aspects of the accessibility of the digital platforms of the universities and together with proposed solutions developed and verified with the participation of end-users.

\section{Acknowledgement}

This article was written with the support of the Grant Agency of the Czech Republic, registration number: 14-33854P (e-Accessibility for Students with Visual Impairment at Universities in the Czech and Slovak Republic). 


\section{References}

Caldwell, B., Cooper, M., Guarino Reid, L., \& Vanderheiden, G. (2008). Web Content Accessibility Guidelines (WCAG) 2.0. Retrieved from https://www.w3.org/TR/WCAG20/.

Center for History and New Media. (n.d.). Rýchly sprievodca. Retrieved from http://zotero.org/ support/quick_start_guide.

Chisholm, W., Vanderheiden, G., \& Jacobs, I. (Eds.). (1999). Web Content Accessibility Guidelines 1.0. Retrieved from https://www.w3.org/TR/WCAG10/.

Craig, J., \& Cooper, M. (Eds.). (2014). Accessible Rich Internet Applications (WAI-ARIA) 1.0. Retrieved from https://www.w3.org/TR/wai-aria/.

Hickson, I., Berjon, R., Faulkner, S., Leithead, T., Doyle Navara, E., O'Connor, E., \& Pfeiffer, S. (Eds.). (2014). HTML5. Retrieved from https://www.w3.org/TR/html5/.

Ibanescu, L. (2011). How Screen Readers Speak A Page With HTML5 and ARIA. Retrieved from: <http:// cssgallery.info/how-screen-readers-speak-a-page-with-html5-and-aria/>.

Ministerstvo financií Slovenskej republiky. (2014). Výnos č. 55/2014 Z. z. Výnos Ministerstva financií Slovenskej republiky o štandardoch pre informačné systémy verejnej správy. Retrieved from: http://www.epi.sk/zz/2014-55.

Ministerstvo vnitra České republiky. (2008). Metodický pokyn k vyhlášce č. 64/2008 Sb., o formě uveřejňování informací souvisejících s výkonem veřejné správy prostřednictvím webových stránek pro osoby se zdravotním postižením (vyhláška o prístupnosti). Retrieved from: http:// www.mvcr.cz/clanek/metodicky-pokyn-k-vyhlasce-c-64-2008-sb-o-forme-uverejnovani-informaci-souvisejicich-s-vykonem-verejne-spravy-prostrednictvim-webovych-stranek-pro-osobyse-zdravotnim-postizenim-vyhlaska-o-pristupnosti.aspx.

NV Access. (2016). NVDA screen reader (Version 2016.4). Queensland: NV Access. Retrieved from: http://www.nvaccess.org/.

Pavlíček, R. (2005). Blind Friendly Web. Retrieved from: http://blindfriendly.cz/download/doc/bfw23. pdf

Regec, V. (2014) Visual Impairment and Digital Barriers at University and College Web Portals. In 8th International Technology, Education and Development Conference. INTED2014 Proceedings. Valencia, pp. 3533-3539.

Regec, V. (2015a) Comparison of Automatic, Manual and Real User Experience Based Testing of Accessibility of Web Sites for Persons with Visual Impairment. Journal of Exceptional People. 3, 1.

Regec, V. (2015b). e-Accessibility in Educating Students with Visual Impairment. In 8th International Conference of Education, Research and Innovation, ICERI2015 Proceedings. pp. 4369-4374.

Regec, V. (2015c). Evaluation of Determinants of E-Accessibility In the Context of Visual Impairment. In 2nd International Multidisciplinary Scientific Conference on Social Sciences and Arts SGEM2015, 2015. pp. 399-406.

Smith, J., \& Whiting, J. (2016). WAVE - web accessibility evaluation tool. WebAIM (Web Accessibility In Mind). Retrieved from: http://wave.webaim.org/.

W3C. (2016). How to Meet WCAG 2.0.

\section{Contact:}

doc. PhDr. Vojtech Regec, Ph.D.

Institute of Special Education Studies

Faculty of Education

Palacký University Olomouc

Žižkovo nám. 5, Olomouc

Czech Republic

E-mail:vojtech.regec@upol.cz
Mgr. Milan Regec

Department of Library and Information Science

Faculty of Arts

Comenius University in Bratislava

Slovak Republic

E-mail:milan.regec@gmail.com 